\title{
Violência doméstica e estrangeiros em Portugal
}

\author{
Domestic violence and foreigners in portugal
}

EMANUEL CARVALHO'

emanuelcarvalho-44900p@adv.oa.pt

GALILEU - REVISTA DE DIREITO E ECONOMIA · e-ISSN 2184-1845

Volume XX $\cdot 1^{\text {st }}$ January Janeiro - 30 ${ }^{\text {TH }}$ June Junho $2019 \cdot$ pp. 122-148

DOI: ???

Submitted on February 27 $7^{\text {th }}, 2019$. Accepted on May $28^{\text {th }}, 2019$

Submetido em 27 de Fevereiro, 2019. Aceite a 28 de Maio, 2019

RESUMO A violência doméstica é um flagelo social que não tem barreiras fronteiriças, podendo emergir em relações entre pessoas da mesma nacionalidade, ou não, e no território de origem das mesmas ou fora daquele. Em Portugal, as vítimas de violência doméstica gozam de um conjunto de direitos que visam garantir a sua protecção e prevenir a sua revitimização. Por força do princípio da equiparação, os estrangeiros que sejam vítimas de violência doméstica e se encontrem em Portugal devem gozar dos mesmos direitos que assistem aos cidadãos nacionais. Porém, a possibilidade daqueles estrangeiros estarem em situação irregular restringe os seus direitos, quando a tutela das vítimas de violência doméstica nunca deveria ser diminuída em função de uma mera irregularidade documental.

PALAVRAS-chaVE violência doméstica; direitos; nacionais; estrangeiros; permanência irregular; princípio da equiparação.

ABSTRACT Domestic violence is a social plague without frontier barriers and may emerge in relations between persons of the same nationality, or not, and in the territory of origin or outside. In Portugal, victims of domestic violence have a set of rights that aim to ensure their protection and avoid their victimization. In line with the principle of equal treatment, foreigners who are victims of domestic violence and stay in Portugal must have the same rights as nationals. However, the possibility of foreigners being in an irregular situation limits their rights, when the victim of violence should never had less rights due to a documentary irregularity.

KEYWORDS domestic violence; rights; nationals; foreigners; illegal stay; assimilation principle.

1 Doutorando em Direito pela Universidade Autónoma de Lisboa. 


\section{Problemática}

A violência doméstica é um flagelo social, que não tem fronteiras e pode atingir qualquer pessoa, independentemente da sua origem, cultura, língua, instrução, capacidade económica, profissão, religião, idade, orientação sexual, saúde, et caetera.

Fixa-se a presente reflexão na violência doméstica perpetuada sobre as mulheres, dado que abundam os estudos e análises estatísticas sobre aquele público-alvo. Neste sentido, evidencia-se que a globalização daquele fenómeno está bem patente na estimativa da Organização Mundial de Saúde de 2013, que apontava que cerca de 35 por cento das mulheres eram ofendidas física ou sexualmente pela pessoa com quem mantinham, ou não, um relacionamento habitual ${ }^{2}$.

Por sua vez, as Nações Unidas previram, em 2012, que a população mundial iria atingir os 7,2 biliões em Julho de 2013 e que a média de nascimentos iria dividir-se, até 2015, em 102 do sexo masculino por cada 100 do sexo feminino3. Ora, o mesmo relatório antevia uma projecção para 2015 de, por um lado, 39,5 crianças apresentarem uma relação de dependência por cada 100 habitantes. E por outro, a população mundial mostrava uma tendência para envelhecer, dado que a idade média prevista para 2015 situava-se em 29,6 e em 2100 crê-se que possa atingir os 41,2.

Conjugando os valores apresentados, nomeadamente a proporção de mulheres adultas no mundo (afastando-se as crianças de sexo feminino que tenham uma relação de dependência) e a percentagem de ofensas perpetradas naquelas, pode-se estimar que em 2013 foram, globalmente, vítimas cerca de 497 milhões de mulheres.

Este cômputo (ainda que seja uma estimativa) conduz forçosamente a um sentimento de inquietação atual e atenta a possibilidade da população - reitera-se - ter tendência para envelhecer, pode representar uma preocupação acrescida para os tempos subsequentes e próximas gerações.

Portugal integra este problema de ordem mundial e, como tal, expõem-se os indicadores nacionais que se reportam ao ano 2013, de modo a efetuar-se um paralelo com os valores acima indicados e, assim, se garantir à presente reflexão uma maior harmonia temporal entre os elementos expostos. Isto sem preterir que existam informações, internamente, mais recentes, sendo que algumas destas são sobejamente preocupantes, como, por um

2 ORGANIZAÇÃO MUNDIAL DA SAÚDE - Estimativas globais e regionais da violência contra as mulheres: prevalência e efeitos da violência conjugal e da violência sexual não conjugal na saúde. [Consultado em 07 de Maio de 2019]. Disponível em: http://apps.who.int/iris/bitstream/handle/10665/85239/9789241564625 _eng. pdf? sequence $=1$

3 NAÇÕES UNIDAS - World Population Prospects: The 2012 Revision, Volume II, Demographic Profiles. [Consultado em 07 de Maio de 2019]. Disponível em: https://population.un.org/wpp/Publications/Files/ WPP2012_Volume-II-Demographic-Profiles.pdf 
lado, a taxa de femicídio mais elevada dos últimos anos se ter situado no ano 2014, no qual se registaram a consumação de 45 homicídios contra mulheres. E por outro, verificaram-se entre o ano de 2004 e 2018 cerca de 503 femicídios, o que confere uma estonteante média de 35 a 36 vítimas por ano ${ }^{4}$.

O Relatório Anual de Segurança Interna (RASI) ${ }^{5}$ respeitante ao ano 2013 contabilizou 22.928 participações efetuadas às autoridades, que se enquadram no crime de violência doméstica, o que traduz uma média aproximada de 63 sinalizações por dia ou quase 3 casos por hora ${ }^{6}$. Este tipo de criminalidade evidenciou uma tendência crescente nos últimos anos dado que, em 2017, o RASI registou 26.713 situações do mesmo género, o que traduz um aumento de 3.785 denúncias ${ }^{7}$.

O referido RASI de 2013 aponta que o Serviço de Estrangeiros e Fronteiras (SEF) procedeu ao afastamento coercivo de 217 cidadãos estrangeiros associados à criminalidade violenta. As nacionalidades daqueles cidadãos são várias, dividindo-se as três de maior monta pela brasileira, cabo-verdiana e angolana, com, respectivamente, 65, 42 e 23 pessoas. E os tipos de crime praticados pelos cidadãos afastados do território nacional prendem-se, esmagadoramente, com o crime de tráfico de estupefacientes, roubo e furto, com, respectivamente, 108, 50 e 22 casos. Embora de menor expressão, o mesmo relatório contabilizou 3 situações relacionadas com o crime de violência doméstica ${ }^{8}$.

O Alto Comissariado para as Migrações, particularmente o Observatório das Migrações, indicou no relatório estatístico anual de 2016 que a condenação por crimes de violência doméstica contra cônjuges ou análogos, em 2013, aplicada a cidadãos portugueses foi superior do que aquela empregue a estrangeiros, tendo-se, respectiva e aproximadamente,

4 UMAR - Relatório do Observatório de Mulheres Assassinadas. [Consultado em o7 de Maio de 2019]. Disponível em: http://www.umarfeminismos.org/images/stories/noticias ／OMA_FEMIC\%C3\%8DDIO_Relat\%C3\%B3rio_2018_ em_18_02_2019.pdf

5 O RASI é um instrumento elaborado pela Direcção-Geral de Política de Justiça (DGPJ) com o intuito de aferir, anualmente, a criminalidade participada em Portugal.

6 PORTUGAL - Sistema de Segurança Interna - Relatório Anual de Segurança Interna de 2013. [Consultado em 07 de Maio de 2019]. Disponível em: https://www.portugal .gov.pt/media/1391220/RASI\%202013.pdf

7 PORTUGAL - Sistema de Segurança Interna - Relatório Anual de Segurança Interna de 2017. [Consultado em 07 de Maio de 2019]. Disponível em: https://www.portugal.gov.pt /download-ficheiros/ficheiro.aspx? v=9fod7743-7d45-40f3-8cf2-e4486oof3af6

8 Conferir pág. 184 do relatório referido na nota de rodapé n. ${ }^{\circ}$ 7. Comparando o afastamento de estrangeiros registados no RASI de 2013 e no RASI de 2017 verifica-se que aumentaram, tendo-se registado em 2017 o afastamento de 281 cidadão estrangeiros associados à prática de crimes, prevalecendo maioritariamente entre estes o crime de tráfico de estupefacientes com 106 casos. Desta vez, aquele relatório não descreveu de modo autónomo os casos de crimes de violência doméstica, que eventualmente poderão ter existido e, assim sendo, poderão estar mitigados na rubrica dos apelidados "outros crimes". Conferir pág. 85 do relatório referido na nota de rodapé $n .^{0} 7$. 
verificado 52 e 42 condenações ${ }^{9}$. Esta relação evidencia-se no mesmo sentido quanto à prisão efectiva aplicada aos arguidos dado que, em 2013, foram presos por crimes de violência doméstica, em média, 3 cidadãos portugueses face a 1 cidadão estrangeiro ${ }^{10}$. Decorre, por fim, do mesmo relatório que, em 2013, foram registadas 50 vítimas que se apresentaram à Unidade de Apoio à Vitima, sob a gestão da organização sem fins lucrativos sobejamente conhecida em Portugal pela sigla APAV (Associação de Apoio à Vitima) ${ }^{11}$.

Importa, ainda, evidenciar que o SEF registou, em 2013, 401.320 estrangeiros regulares, correspondendo 51,27\% a mulheres e 48,73\% a homens. Desde, então, a evolução foi no sentido daquele número de estrangeiros aumentar, tendo atingido os 421.711. Embora a divisão percentual entre mulheres e homens se tenha mantido quase idêntica, repartindo-se, respetivamente, entre $51,18 \%$ e $48,82 \%{ }^{12}$.

O roteiro percorrido até agora serviu para assinalar, por um lado, que em Portugal é alarmante a violência doméstica verificada atualmente sobre as mulheres. E por outro, a violência doméstica tem sido mais disseminada por e entre cidadãos portugueses do que estrangeiros. Acontece que estes últimos - e, em particular, as vítimas, que são o enfoque desta análise - podem estar sujeitos ao afastamento do território nacional caso estejam numa situação irregular.

Posto isto, pretende-se reflectir sobre as consequências jurídicas do eventual afastamento de um cidadão estrangeiro do nosso território por estar numa situação irregular e que tenha sido vítima de um crime de violência doméstica por parte do progenitor de filho(s) em comum. Concretizando, a proteção da vida familiar dos estrangeiros, ainda que em situação irregular, é um limite efetivo ao princípio da soberania territorial em matéria de direito dos estrangeiros?

\section{Concetualização}

A reflexão proposta impõe, previamente, um enquadramento concetual, designadamente da noção de violência doméstica, de vítima e de (cidadão) estrangeiro.

9 OLIVEIRA REIS, Catarina (Coord.); GOMES, Natália - Indicadores de Integração de Imigrantes: Relatório Estatístico Anual de 2016. Lisboa: Alto Comissariado para as Migrações, 2016.

10 Conferir pág. 165 do estudo mencionado na nota de rodapé n. ${ }^{\circ} 9$.

11 Atualmente aquela unidade apelida-se de Unidade de Apoio à Vitima Migrante e de Descriminação. Cf. https:// apav.pt/uavmd/index.php/pt/

12 SEFSTAT é o portal online de estatística do SEF. Cf. https://sefstat.sef.pt/forms/distritos.aspx 
O conceito legal de violência doméstica, que vigora no ordenamento jurídico português, foi recentemente introduzido pela Lei n. ${ }^{0} 59 / 2007^{13}$, a qual originou a vigésima terceira alteração ao Código Penal ${ }^{14}$.

Em concreto, aquele diploma impôs uma redação integralmente nova ao artigo $152 .^{\circ}$, que na sua epígrafe acolheu a expressão "Violência Doméstica", provocando uma mudança atípica na sistematização do Código Penal. Isto porque ao projetar para o artigo 152 . $^{\circ}$-A o tipo legal de crime de "Maus tratos" (que embora tenha sido formulado, ex novo, pela referida Lei n. ${ }^{\circ}$ 59/2007, acolheu parte do teor do anterior preceito $152 .^{\circ}$, que tinha por epígrafe "Maus tratos e infração de regras de segurança") fez antepor a forma de crime especial face ao crime geral ${ }^{15}$.

Observando o referido artigo $152 .^{\circ}$ do Código Penal é no seu número 1, que encontramos o que se pode considerar como sendo a definição legal de violência doméstica. Assim e sem preterir que uma norma penal consubstancia, por um lado, a ultima ratio da política criminal ou o princípio da intervenção mínima imposta pelo artigo $18 .^{\circ}, n^{\circ}{ }^{\circ} 2$ da Constituição da República Portuguesa (CRP), e encontra, por outro, a sua fonte de legitimação material na Lei Fundamental ${ }^{16}$, o legislador considera que:

"Quem, de modo reiterado ou não, infligir maus tratos físicos ou psíquicos, incluindo castigos corporais, privações da liberdade e ofensas sexuais:

a) Ao cônjuge ou ex-cônjuge;

b) A pessoa de outro ou do mesmo sexo com quem o agente mantenha ou tenha mantido uma relação de namoro ou uma relação análoga à dos cônjuges, ainda que sem coabitação;

c) A progenitor de descendente comum em $1 .^{\circ}$ grau; ou

d) A pessoa particularmente indefesa, nomeadamente em razão da idade, deficiência, doença, gravidez ou dependência económica, que com ele coabite;

13 A Lei n. ${ }^{\circ}$ 59/2007, foi publicada em Diário da República, $1 . .^{a}$ série - N. ${ }^{\circ} 170-4$ de Setembro de 2007.

14 O Código Penal aprovado pelo Decreto-Lei n. ${ }^{\circ} 400 / 82$, de 23 de Setembro, foi revisto e publicado na íntegra pelo Decreto-Lei n. ${ }^{\circ}$ 48/95, de 15 de Março, somando este até ao presente com mais de 40 alterações.

15 ALBUQUeRQUE, Paulo Pinto de - Comentário do Código Penal à luz da Constituição da República e da

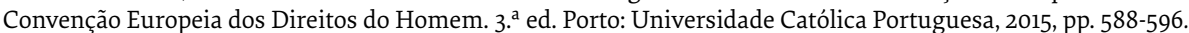

16 BRANDÃO, Nuno - Bem Jurídico e Direitos Fundamentais entre a Obrigação Estadual de Protecção e a Proibição do Excesso. In Estudos em Homenagem ao Prof. Doutor Manuel da Costa Andrade. Coimbra: Instituto Jurídico, 2017, pp. 239-266. 
é punido com pena de prisão de um a cinco anos, se pena mais grave lhe não couber por força de outra disposição legal."

Dado o primado do direito internacional sobre o direito constitucional ${ }^{17}$, vigora, igualmente, no nosso sistema jurídico outra definição de violência doméstica, imposta pela denominada Convenção de Istambul, à qual Portugal foi o primeiro país da União Europeia a aderir em $2013^{18}$.

Assim, o artigo $3^{\circ}$, alínea b), da Convenção de Istambul estabelece que: «"violência doméstica" designa todos os actos de violência física, sexual, psicológica ou económica que ocorrem no seio da família ou do lar ou entre os actuais ou ex-cônjuges ou parceiros, quer o infractor partilhe ou tenha partilhado, ou não, o mesmo domicílio que a vítima”».

A partir dos referidos conceitos legais pode-se interpretar a violência doméstica numa perspectiva subjectiva, que será marcada pela relação entre a pessoa que domina (agente do crime) e a pessoa que é dominada (ofendida), e num prisma objectivo, que consistirá nas condutas que configuram a sua ilicitude.

A variedade daquela subjectividade pauta-se pela existência de um vínculo de parentesco (por exemplo, a relação entre cônjuges ou entre pais e filhos), ou não (por exemplo, unidos de facto ou numa relação de namoro), sendo certo que aquele existente entre o progenitor e descendente em linha reta não deve ir além do primeiro grau.

Pode aproximar pessoas de diferentes géneros ou não. Ainda que a relação de violência doméstica mais divulgada à escala global, não sendo Portugal exceção, seja perpetuada pelo homem contra a mulher, é hoje garantida proteção legal para a população conhecida pela sigla "LGBTI", que engloba as pessoas lésbicas, gays, bissexuais. transexuais e intersexuais.

A relação subjectiva assume uma dimensão ampla a partir do momento que o legislador previu que, por um lado, pode haver coabitação, ou não, entre o agressor e a vítima. E por outro, a pessoa "dominada" pode ser aquela que esteja numa situação de especial vulnerabilidade em função da "idade, deficiência, doença, gravidez ou dependência económica".

17 Artigo $8 .^{\circ}$, n. ${ }^{\circ} 2$ da CRP estatui que: "as normas constantes de convenções internacionais regularmente ratificadas ou aprovadas vigoram na ordem interna após a sua publicação oficial e enquanto vincularem internacionalmente o Estado Português."

18 Por Decreto do Presidente da República n. ${ }^{\circ}$ 13/2013, publicado em Diário da República, 1.. ${ }^{a}$ série - N. ${ }^{\circ} 14-21$ de janeiro de 2013, foi "ratificada a Convenção do Conselho da Europa para a Prevenção e o Combate à Violência contra as Mulheres e a Violência Doméstica, adotada em Istambul, a 11 de maio de 2011, aprovada pela Resolução da Assembleia da República n. ${ }^{\circ}$ 4/2013, em 14 de dezembro de 2012." 
Num ângulo objectivo, a violência doméstica pressupõe uma conduta ofensiva que pode ser singular ou reiterada ${ }^{19}$. Ainda que se reprima individualmente um ato, é mais frequente a forma de violência exercida pelo agente de forma repetida sobre a ofendida.

Neste momento importa refletir sobre a dinâmica da violência doméstica, pelo que se convoca um modelo teórico sobejamente conhecido - o modelo de "Duluth" ${ }^{20}$ - na caraterização da relação subjacente à violência. De acordo com o referido modelo, a relação entre o agressor e a vítima é, resumidamente, marcada pela tentativa e consumação do "poder-controlo" do primeiro sobre a segunda. Este "poder-controlo" é concretizado de modo cíclico e mediante diversas fases.

Inicialmente, o agressor procura "seduzir" a vítima, conquistar a sua confiança e fazer crer através de afetos que os dois podem viver sozinhos de modo feliz, com vista a isolar aquela das suas relações sociais, familiares e até profissionais, recorrendo a sugestões subtis para convencer a vítima a abandonar qualquer ligação com terceiros.

Seguidamente, as ofensas iniciam-se com meras condutas intimidatórias e pressões psicológicas ou verbais, para rapidamente evoluírem para o patamar das ameaças e, posteriormente, para a consumação de agressões físicas, que por sua vez passam rapidamente de atos leves (por exemplo, bofetadas ou safanões) a condutas de elevada gravidade (por exemplo, estrangulamento, abuso sexual ou tentativa de homicídio).

Por fim, a violência pode abrandar ou cessar e dar lugar novamente a uma etapa de "sedução" ou aliciação, embora esta seja pautada por manifestações aparentes ou enganadoras do arrependimento do agressor. A intenção deste é tão-somente retomar o início do ciclo para reforçar o "poder-controlo" sobre a vítima. Esta situação apresenta-se de enorme perigosidade para a vítima, dado que o perdão ou a aceitação do agressor reabre o caminho para aquele retomar os atos de violência, que têm tendência para, quando se repetem, agravar-se na sua intensidade.

Retomando a perspectiva objectiva, o artigo $152 .{ }^{\circ}$ do Código Penal prevê a repressão de condutas pautadas por violência física, psicológica, verbal e sexual.

Concretizando, o legislador reprova, primeiro, comportamentos de cariz físico, ainda que estes possam assumir uma intensidade menor ou maior de violência. Segundo, são

19 A jurisprudência tem considerado que após a Lei n. ${ }^{\circ}$ 59/2017, que provocou a vigésima terceira alteração ao Código Penal, dissipou-se a querela que pairava sobre o anterior artigo 152. ${ }^{\circ}$ do Código Penal - "Maus Tratos" - dado que a atual redação daquele artigo é expresso em admitir que para preencher-se o tipo legal de crime de violência doméstica pode ser suficiente a prática de um só ato ou pode ocorrer com a repetição de condutas ilícitas. Conferir os seguintes arestos: Ac. do TRG, no proc. n. ${ }^{\circ}$ 639/08.6GBFLG.G1, de 15/10/2002; Ac. do TRL, no proc. n. ${ }^{\circ}$ 3/16.oPAPST.L1-9, de 01-06/2017; Ac. do TRC, no proc. n. ${ }^{\circ}$ 1290/12.1PBAVR.C1, de 29/01/2004 (consultados em 22/02/2019). Disponível em: http://www.dgsi.pt.

20 Disponível em: https://www.theduluthmodel.org/wheels/ (consultado em 07/05/2019). 
desaprovadas ofensas de natureza verbal ou emocional (constituídas, por exemplo, por injúrias ou expressões que visam denigrir a honra ou a imagem da vítima). Terceiro, são censuradas as condutas que restrinjam a liberdade e autonomia da ofendida, no sentido em que possam reduzir a sua capacidade para tomar decisões ou movimentar-se, ou, em sentido oposto, que possam forçar a vítima a atuar contra a sua vontade. Quarto, são proibidas condutas que atentem contra a liberdade sexual da ofendida. Quinto (e último), são reprovados comportamentos em que o agressor interfira na autonomia financeira da ofendida ${ }^{21}$.

Para concluir o conceito de violência doméstica, resta a partir da conduta típica e ilícita exposta descrever os bens jurídicos tutelados pelo artigo $152 .^{\circ}$ do Código Penal. Neste aspeto, a consonância doutrinal e jurisprudencial não é unânime e, em síntese, podem-se apontar as seguintes posições.

TAIPA DE CARVALHO afirma: “(...) o bem jurídico protegido por este tipo de crime é a saúde - bem jurídico complexo que abrange a saúde física, psíquica e mental, e bem jurídico este que pode ser afectado por toda a multiplicidade de comportamentos que impeçam ou dificultem o normal e saudável desenvolvimento da personalidade da criança ou do adolescente, agrave as deficiências destes, afectem a dignidade pessoal do cônjuge (...)"22.

PINTO DE ALBUQUERQUE defende que os bens tutelados são a "integridade física e psíquica, liberdade pessoal, a liberdade e autodeterminação sexual e até a honra”23.

Nos tribunais tem, ainda, sido preconizado que o artigo $152 .^{\circ}$ do Código Penal visa tutelar não só a saúde, mas igualmente a integridade pessoal, que merece dignidade constitucional conforme o seu artigo $25 \cdot{ }^{024}$.

21 A jurisprudência tem afirmado recorrentemente que a violência doméstica pode configurar-se mediante uma "agressão económica" e, em exemplo, dessa dimensão autónoma tem sido decidido que se preenche o tipo legal previsto no artigo $152 .^{\circ}$ quando o comportamento do agente impossibilita a ofendida de gerir os seus rendimentos. Conferir os seguintes arestos: Ac. do TRC, no proc. n. ${ }^{\circ}$ 663/16.5PBCTB.C1, de 07/02/2018, e o Ac. do TRG, no proc. n. ${ }^{\circ}$ 201/16.06GBBCL.G1, de 06/02/2017 (consultados em 22/02/2019). Disponível em: http://www. dgsi.pt/.

Em sentido diferente, PAULO PINTO DE ALBUQUERQUE afirma que aquela agressão financeira "deve ser subsumida aos maus-tratos psíquicos, isto é, a uma particular modalidade de violência psicológica em consonância com o conceito amplo de violência doméstica da Convenção de Istambul". Conferir nota 7 do artigo $152 .{ }^{\circ}$ da ob. citada na nota de rodapé n. ${ }^{\circ} 15$.

22 CARVALHO, Taipa de - Comentário Conimbricense do Código Penal, Tomo I, Coimbra, Coimbra Editora, 1999, p. 332. Comungam desta posição: SÁ GOMES, Catarina - O Crime de Maus Tratos Físicos e Psíquicos Infligidos ao Cônjuge ou ao Convivente em Condições Análogas às dos Cônjuges. Lisboa: AAFDL, 2004, p. 59; FERNANDES, Plácido Conde - Violência doméstica: novo quadro penal e processual penal. In Revista do CEJ. Lisboa. ISSN 1645-829X. N. ${ }^{\circ}$ 8, 2004, p. 239-340, p. 305; GARCIA, M. Miguez; RIO, J. M. Castela - Código Penal Anotado. Lisboa: Almedina, 2015, em notas ao artigo $152 .^{\circ}$.

Nesta esteira conferir os seguintes arestos: Ac. do TRP, proc. n. ${ }^{\circ}$ 176/11.1SLPRT.P1, de 26/09/2012 e o Ac. do TRC, proc. n. ${ }^{\circ}$ 182/06.8TAACN, de 19/11/2008 (consultados em 22/02/2019). Disponível em: http://www.dgsi.pt/.

23 Conferir nota 2 da ob. citada na nota de rodapé $n .{ }^{\circ} 15$.

24 Conferir o ponto I do sumário do Ac. do TRL, proc. n. ${ }^{\circ}$ 3/16.0T.L1-9, de 01/06/2017 (consultado em 22/02/2019). Disponivel em: http://www.dgsi.pt/. 
Em suma, seja por força da tutela da dignidade humana ${ }^{25}$ ou da integridade pessoal ${ }^{26}, \mathrm{o}$ bem ou bens jurídicos tutelados pela referida norma penal encontra expressão e protecção na nossa Lei Fundamental.

Avançando para o conceito legal de vítima em vigor no nosso ordenamento jurídico, convoca-se o Código de Processo Penal, aprovado pelo Decreto-Lei n. ${ }^{0} 78 / 87^{27}$, que mediante o aditamento imposto pela Lei n. ${ }^{\circ} 130 / 2015^{28}$, introduziu o artigo $67 .^{\circ}$-A sob a epígrafe "Vítima"29.

Sucede, porém, que antes daquele aditamento ao Código de Processo Penal já estava em vigor a Lei n. ${ }^{\circ}$ 112/2009, que veio estabelecer "o regime jurídico aplicável à prevenção da violência doméstica, à protecção e à assistência das suas vítimas"30.

Resulta deste diploma, logo no seu artigo 2. ${ }^{\circ}$, a noção de vítima nos seguintes termos:

“(... a) «Vítima» a pessoa singular que sofreu um dano, nomeadamente um atentado à sua integridade física ou psíquica, um dano emocional ou moral, ou uma perda material, diretamente causada por ação ou omissão, no âmbito do crime de violência doméstica previsto no artigo 152. ${ }^{\circ}$ do Código Penal;

b) «Vítima especialmente vulnerável» a vítima cuja especial fragilidade resulte, nomeadamente, da sua diminuta ou avançada idade, do seu estado de saúde ou do facto de o tipo, o grau e a duração da vitimização haver resultado em

$25 \mathrm{O}$ artigo $1 .^{\circ}$ da CRP estatui que: "Portugal é uma República soberana, baseada na dignidade da pessoa humana e na vontade popular e empenhada na construção de uma sociedade livre, justa e solidária."

$26 \mathrm{O}$ artigo $25^{\circ}{ }^{\circ}$,.$^{\circ} 1$ da CRP reza que: "A integridade moral e física das pessoas é inviolável."

27 O Decreto-Lei n. ${ }^{\circ} 78 / 87$ foi publicado em Diário da República, $1 .{ }^{a}$ série - N. ${ }^{\circ} 40-17$ de Fevereiro de 1987 . Aquele diploma revogou o anterior Código de Processo Penal estatuído pelo Decreto-Lei n. ${ }^{\circ} 16489$, de 15 de Fevereiro de 1929, e demais legislação avulsão que o complementou.

28 A Lei n. ${ }^{0}$ 130/2015 foi publicada em Diário da República, $1 .{ }^{a}$ série - N. ${ }^{\circ} 173-4$ de Setembro de 2015. Aquele diploma "procede à vigésima terceira alteração ao Código de Processo Penal e aprova o Estatuto da Vítima, transpondo a Diretiva 2012/29/UE do Parlamento Europeu e do Conselho, de 25 de outubro de 2012, que estabelece normas relativas aos direitos, ao apoio e à proteção das vítimas da criminalidade e que substitui a Decisão-Quadro 2001/220/JAI do Conselho, de 15 de março de 2001".

29 O artigo 67..$^{\circ}$-A estatui o seguinte:

1 - Considera-se:

a) 'Vítima':

i) A pessoa singular que sofreu um dano, nomeadamente um atentado à sua integridade física ou psíquica, um dano emocional ou moral, ou um dano patrimonial, diretamente causado por ação ou omissão, no âmbito da prática de um crime;

ii) Os familiares de uma pessoa cuja morte tenha sido diretamente causada por um crime e que tenham sofrido um dano em consequência dessa morte;

b) 'Vítima especialmente vulnerável', a vítima cuja especial fragilidade resulte, nomeadamente, da sua idade, do seu estado de saúde ou de deficiência, bem como do facto de o tipo, o grau e a duração da vitimização haver resultado em lesões com consequências graves no seu equilíbrio psicológico ou nas condições da sua integração social;". 30 A Lei n. ${ }^{\circ} 112 / 2009$ foi publicada em Diário da República, $1 .{ }^{a}$ série - N. ${ }^{0} 180-16$ de Setembro de 2009. 
lesões com consequências graves no seu equilíbrio psicológico ou nas condições da sua integração social; (...)".

Ora, é seguro afirmar que é este último conceito que deve ser tido em conta nesta reflexão, dado que aquele integra um regime jurídico especialmente associado à repressão do crime de violência doméstica. Ainda assim, e por comparação com a noção integrante na lei geral - entenda-se no Código de Processo Penal -, constata-se que o artigo $67 .^{\circ}$-A não acrescenta qualquer elemento relevante que seja adequado levar-se aqui em consideração.

Confrontando o conceito de "vítima" e "vítima especialmente vulnerável" com o tipo legal de crime de violência doméstica verifica-se uma correlação intrínseca entre ambos. Por um lado, porque as condutas que se pretendem reprimir - nomeadamente, a violência física, psicológica, verbal, económica e sexual - representam os diferentes tipos de danos que poderão ser infligidos na pessoa ofendida. E por outro, porque a pessoa ofendida que o referido tipo legal de crime visa proteger, por estar numa situação de especial vulnerabilidade em função da "idade, deficiência, doença, gravidez ou dependência económica", faz sobressair que aquela possa ser considerada uma "vítima especialmente vulnerável".

Por fim, a identificação de (cidadão) estrangeiro no nosso ordenamento jurídico verifica-se, imediatamente, na Constituição da República Portuguesa (CRP).

Ainda que o artigo $15 .^{\circ}$ da CRP, sob a epígrafe "Estrangeiros, apátridas, cidadãos europeus", não apresente uma noção expressa de estrangeiro, efetua um claro reconhecimento do seu estatuto jurídico, dado que consagra que aquele, por se encontrar ou residir em Portugal, goza dos mesmos direitos e está obrigado aos mesmos deveres do cidadão português.

A alusão ao cidadão português obriga, agora, a refletir sobre quem se pode considerar titular da cidadania portuguesa. E apreciando, novamente a CRP, o artigo $4 .^{\circ}$ aponta, embora de modo muito circunscrito, que os cidadãos portugueses são "todos aqueles que como tal sejam considerados pela lei ou por convenção internacional."

Feita a conjugação de ambos os preceitos fundamentais - artigo $4 .^{\circ}$ e artigo $15 .^{\circ}$ - pode-se inferir que um cidadão estrangeiro é uma pessoa que resida ou se encontre em território português, ao qual não é atribuído pelo direito interno ou internacional, o direito a adquirir a cidadania portuguesa. ${ }^{31}$

Acresce que o reconhecimento atual de uma cidadania europeia, imposta pela ordem jurídica comunitária, vem limitar aquele conceito de estrangeiro aos cidadãos que não sejam nacionais de qualquer Estado-membro da União Europeia. Isto porque e apenas

31 CANOTILHO, Gomes; MOREIRA, Vital - Constituição da República Portuguesa Anotada. Vol. I. 4.. ${ }^{\mathrm{a}}$ ed. rev. Coimbra: Coimbra Editora, 2007, p. 357. 
focando o aspecto que mais importa para esta análise, os cidadãos da União Europeia gozam da liberdade de circulação de pessoas, de residência e de trabalho por todo o território daquela União.

A diferença fundamental que separa um cidadão português de um estrangeiro reside na capacidade de gozo de maior ou menor número de direitos, bem como de sujeição a deveres, dado que a CRP estabelece o princípio da equiparação entre aqueles, embora com limitações para o estrangeiro, que se prendem no mais importante com a vedação deste ao exercício da soberania nacional ${ }^{32}$.

Embora a CRP efetue o reconhecimento de (cidadão) estrangeiro, é em lei ordinária que se encontram definidas "as condições e procedimentos de entrada, permanência, saída e afastamento de cidadãos estrangeiros do território português"33.

Observado este diploma salientam-se duas definições que (mais adiante se vão relevar essenciais para a presente reflexão e) são: "Regresso"34 e "Residente legal"35.

À luz da referida lei, pode-se considerar estrangeiro a pessoa que se encontre ou resida em Portugal de modo legal. Porém, quando se verificar, por qualquer motivo, que o cidadão estrangeiro deixe de possuir uma autorização válida para permanecer no território português, pode ser afastado do território português e ser obrigado a regressar ao país da sua naturalidade ou ao país de onde proveio ou, ainda, ao país que escolha, desde que este o aceite ${ }^{36}$.

\section{Violência doméstica e estrangeiros em Portugal}

Portugal possui movimentos migratórios compostos pelos cidadãos que pretendem sair do nosso território - fluxo emigratório - e pelos cidadãos que pretendem ingressar em solo português - fluxo imigratório.

32 Artigo $15 .^{\circ}, \mathrm{n} .{ }^{\circ} 2$ da CRP estatui o seguinte: "Exceptuam-se do disposto no número anterior os direitos políticos, o exercício das funções públicas que não tenham carácter predominantemente técnico e os direitos e deveres reservados pela Constituição e pela lei exclusivamente aos cidadãos portugueses."

33 A Lei n. ${ }^{\circ}$ 23/2007 foi publicada em Diário da República, 1.. ${ }^{a}$ série - N. ${ }^{0} 127-4$ de Julho de 2007 . Esta lei é comumente designada por Lei de Estrangeiros e já foi objeto de diversas alterações legais, tendo a última sido operada pela Lei n. ${ }^{\circ} 26 / 2018$, de 5 de Julho.

34 Artigo $3 .^{\circ}, \mathrm{n} .^{\circ} 1$, alínea u), da lei citada na nota de rodapé $n .^{\circ} 33$.

35 Artigo $3 .^{\circ}, \mathrm{n} \cdot{ }^{\circ} 1$, alínea v), da lei citada na nota de rodapé $n .{ }^{\circ} 33$.

$36 \mathrm{O}$ afastamento do cidadão estrangeiro de Portugal não tem um caráter absoluto atento o princípio do "non-refoulement". Este é um princípio imperativo que emana do direito internacional, sendo, por isso, considerado como ius cogens, segundo o qual não se deve repelir o cidadão estrangeiro para um Estado onde seja ameaçada a sua vida ou a sua liberdade. No nosso ordenamento jurídico, aquele princípio encontra-se espelhado na Lei de Concessão de Asilo ou Proteção Subsidiária (aprovada pela Lei n. ${ }^{\circ}$ 27/2008, que foi publicada no Diário da República, 1.. ${ }^{\mathrm{a}}$ série - N. ${ }^{\circ} 124-30$ de Junho de 2008 ), nomeadamente no artigo $2^{\circ}$, n. ${ }^{\circ} 1$, alínea aa) e no artigo $47 .^{\circ}$. 
Ambos os fluxos são realizados por cidadãos portugueses, cidadãos europeus ou cidadãos estrangeiros, e são efectuados de modo a que o seu sentido muda tão frequentemente, que até se pode perder a noção de quem entra ou sai do território ${ }^{37}$.

O crescente fluxo migratório tem proporcionado a criação de laços familiares entre cidadãos nacionais e estrangeiros, ora mediante a constituição de matrimónios, que a doutrina apelida de "casamentos transnacionais", ora por situações de união de fato, não sendo Portugal exceção a este fenómeno ${ }^{38}$.

A correlação entre, por um lado, a constituição de uma família composta por cidadãos portugueses e cidadãos estrangeiros, e por outro, a violência doméstica, é evidente uma vez que a relação familiar consubstancia um contexto potenciador para a ocorrência do crime de violência doméstica.

Acresce que aquela conexão torna-se especial na medida em que a pessoa estrangeira pode estar isolada e, assim, à mercê do agente do crime, que almeja pelo controlo da vítima. Este isolamento pode assumir diferentes feições, tais como a vítima estar afastada geograficamente da sua família e demais pessoas em quem confiava, não dominar a língua do país onde reside, não possuir trabalho, et ccetera.

Ora, ocorrendo a prática de um crime de violência doméstica contra uma pessoa estrangeira que se encontre - permanente ou temporariamente - em Portugal, a vítima beneficia de um conjunto de direitos e garantias fundamentais idênticos àqueles que são facultados aos cidadãos portugueses, por força do princípio da equiparação previsto no artigo $15 .^{\circ}$ da CRP.

Emerge, logo à cabeça, entre aqueles direitos a faculdade de apresentar queixa ${ }^{39}$. E esta pode ser exercida, pessoalmente, junto das autoridades policiais (Polícia de Segurança Pública $^{40}$ ou Guarda Nacional Republicana) ou dos serviços competentes do Ministério Público ou, ainda, mediante a apresentação de uma queixa eletrónica ${ }^{41}$. Embora o ato de queixa seja pessoal, a vítima estrangeira pode em Portugal contar com o auxílio de entidades que apoiam vítimas de violência doméstica (como, por exemplo, a APAV ${ }^{42}$, UMAR ${ }^{43}$,

37 ROCHA-TRINDADE, Maria Beatriz - Sociologia das Migrações. Lisboa: Universidade Aberta de Lisboa, 1995, p. 33.

38 TOGNI, Paula (coord.); RAPOSO, Paulo - Fluxos Matrimonais Transnacionais entre Brasileiras e Portugueses: Género e Imigração. Estudos do Observatório da Migração do Alto Comissariado para as Migrações, n. ${ }^{\circ} 38$, Lisboa, 2009, p. 15.

39 Artigo $113 .{ }^{\circ}$ do Código de Processo Penal e artigo $29 .{ }^{\circ}$ da Lei n. ${ }^{\circ} 112 / 2009$.

40 A queixa pode ser apresentada em qualquer posto da PSP ou GNR, se bem que existem espaços que podem oferecer um atendimento especializado às vítimas de violência doméstica compostos quer por agentes de autoridade, quer por técnicos com habilitações para apoiar aquelas vítimas. Entre estes locais destaca-se o "Espaço Júlia - RIAV (Resposta Integrada de Apoio à Vítima)" situado junto ao Hospital Santo António dos Capuchos na cidade de Lisboa e a "Casa da Maria" localizada na sede da PSP de Oeiras.

41 Disponível em: https://queixaselectronicas.mai.gov.pt (consultado em 07/05/2019).

42 Disponivel em: https://apav.pt/ (consultado em 07/05/2019).

43 Disponivel em: http://www.umarfeminismos.org/ (consultado em 07/05/2019). 
$\mathrm{AMCV}^{44}$ ) ou apoiam imigrantes (como é o caso da Rede CLAIM - Centros Locais de Apoio à Integração de Migrantes) ${ }^{45}$.

Na eventualidade da vítima não apresentar queixa e a partir do momento que uma pessoa ou uma entidade tome conhecimento do crime praticado, tem o dever de denunciar a situação às autoridades competentes acima elencadas, dado que estamos perante um crime de natureza pública ${ }^{46}$. Ainda que haja aquele ónus de denúncia, tem sido praxis dos serviços especializados no apoio às vítimas de violência doméstica gerir o prazo de 6 meses, ao fim do qual prescreve o direito à queixa, no sentido de denunciar no momento em que já se tenha implementado uma estratégia de proteção da vítima, evitando-se que o conhecimento da queixa por parte do agente do crime coloque a vítima numa situação de maior perigo do que aquela em que estava antes da respectiva participação.

Após a referida denúncia e desde que não se constatem fortes indícios daquela ser infundada, é atribuído à vítima pelas autoridades competentes o estatuto de vítima. ${ }^{47}$ Este estatuto "contém um conjunto de medidas que visam assegurar a proteção e a promoção dos direitos das vítimas da criminalidade" 48 e é reduzido a escrito, dado que no final da participação as autoridades competentes entregam à vítima um documento, que elenca os direitos e deveres que assistem à pessoa ofendida, juntamente com uma cópia do auto de notícia ou da apresentação da queixa ${ }^{49}$.

O conjunto de direitos que assistem à vítima merecem um enquadramento legal que se subdivide em tutela policial, judicial e social, chamando-se de seguida à colação aqueles que sejam especificamente mais relevantes para a presente reflexão, embora hajam mais direitos que a protejam do que aqueles que de seguida serão explanados ${ }^{50}$.

Assim e primeiro eleva-se o direito à informação que, por um lado, impõe às autoridades a obrigação de comunicação dos direitos que assistem às vítimas e os deveres que aquelas devem respeitar, bem como toda a dinâmica processual subsequente à participação. E por outro, estabelece que a comunicação deve ser prestada à vítima de modo a que possa com-

44 Disponível em: http://www.amcv.org.pt/ (consultado em 07/05/2019).

45 Contabilizam-se no presente cerca de 100 CLAIM espalhados por Portugal Continental e Insular.

46 A natureza pública do crime de violência doméstica decorre da alteração provocada ao Código Penal pela Lei n. ${ }^{\circ}$ 59/2007 e é uma expressão de protecção máxima da dignidade da pessoa humana.

47 Artigo $14 .^{\circ}$, n. ${ }^{\circ} 1$ da lei citada na nota de rodapé n. ${ }^{\circ} 28$.

48 Conferir nota de rodapé $n .^{\circ} 28$.

49 Artigo $14 .^{\circ}$, n. ${ }^{\circ} 3$ da lei citada na nota de rodapé n. ${ }^{\circ} 28$.

50 Assistem às vítimas de violência doméstica um leque variado de direitos, previstos na Lei n. ${ }^{\circ}$ 112/2009, tais como: celeridade na mudança do tempo de trabalho ou na mobilidade interna, quer esteja ao serviço de uma entidade patronal privada, quer pública (artigo $41 .^{\circ}$ e artigo $42 .^{\circ}$ ); justificação das faltas ao trabalho, sendo remunerada a ausência até 30 dias (artigo 43. ${ }^{\circ}$ ); apoio ao arrendamento ou na obtenção de fogo social (artigo $45^{\circ}$ ); transferência célere do abono de família para a vítima que tenha menores a seu cargo (artigo $47^{\circ}$ ); prioridade no acesso ao emprego e formação profissional (artigo $48 .^{\circ}$ ); tratamento clínico e atendimento especializado pelo Serviço Nacional de Saúde (artigo 49. ${ }^{\circ}$ ); isenção de taxas moderadoras (artigo 50. ${ }^{\circ}$ ). 
preender e ser compreendida. Desta última garantia decorre, essencialmente, o recurso à tradução (quer de documentos, quer de atos orais, mediante a utilização de tradutores ou intérpretes), à aplicação de termos acessíveis e, ainda, à possibilidade da vítima fazer-se acompanhar por outra pessoa em quem confie, que não tem de ser necessariamente um profissional (por exemplo, o advogado), para ajudar aquela a compreender melhor o decurso do processo, desde que tal não interfira com os interesses da ofendida ou com o desenvolvimento processual ${ }^{51}$.

Apenas através destas garantias se pode derrubar um obstáculo enorme constituído, habitualmente, pela língua que os estrangeiros enfrentam em Portugal. Ainda que aqueles possam também ser oriundos dos países que têm como língua oficial a língua portuguesa, é importante destacar que a terminologia técnico-jurídica nem sempre se apresenta acessível à compreensão dos cidadãos.

Segundo, o acesso ao direito, que habitualmente se concretiza ora pela consulta jurídica, ora pelo patrocínio forense. Nesta última faceta, a vítima pode fazer-se acompanhar de advogado perante qualquer autoridade. O legislador estabeleceu, ainda, que a nomeação do mesmo advogado pode ocorrer para os diferentes processos que a vítima de violência doméstica tenha necessidade de instaurar, tais como o processo de divórcio, de regulação das responsabilidades parentais, de promoção e proteção de menores, de alimentos, entre outros, para além do processo-crime. Assim, se previnem as consequências secundárias ou colaterais que a vítima pode sofrer com a necessidade de contar em diferentes ocasiões a sua história de vida e as circunstâncias em que ocorreu o crime de violência doméstica, dado que essa factualidade poderá ser crucial para a instrução dos diferentes processos que a vítima pretenda instaurar ${ }^{52}$. Como apanágio de um direito fundamental, o acesso ao direito, em qualquer umas das referidas aceções, não pode ser limitado por razões de carência económica da vítima ${ }^{53}$.

Terceiro, o direito à proteção garante à vítima medidas adequadas que visem afastar situações de revitimação, de represálias ou de forte perturbação da sua privacidade ${ }^{54}$. A concretização daquele direito manifesta-se de diferentes modos, dos quais se destacam: o evitamento de contato entre a vítima e o arguido em diligências judiciais que impliquem a presença de ambos 55 ; a garantia que o depoimento da vítima em audiência pública seja

51 Artigo $15 .^{\circ}$, da Lei n. ${ }^{\circ} 112 / 2009$, artigo $12 .^{\circ}$ da Lei n. ${ }^{\circ} 130 / 2015$ e artigos $64 .^{\circ}$, n. ${ }^{\circ} 1$ alínea d), $92 .^{\circ}$, n. ${ }^{\circ} 2$ e $166 .^{\circ}$, n. ${ }^{\circ} 1$ do CPP.

52 Artigo $25 .^{\circ}$, n. $^{\circ} 2$, da Lei n. ${ }^{\circ} 112 / 2009$.

53 Artigo $20 .^{\circ}$, n. ${ }^{\circ} 1$ e n. ${ }^{\circ} 2$ da CRP, e artigo $25 .^{\circ}$ da Lei n. ${ }^{\circ} 112 / 2009$.

54 Artigo $20^{\circ}$, n. ${ }^{\circ}$ 1, da Lei n. $.^{\circ} 112 / 2009$ e artigo $15^{\circ}$, n. ${ }^{\circ} 1$, da Lei n. ${ }^{\circ} 130 / 2015$.

55 Artigo $20^{\circ}$, n. ${ }^{\circ} 2$, da Lei n. $.^{\circ} 112 / 2009$ e artigo $15^{\circ}$, n. $^{\circ}$ 2, da Lei n. ${ }^{\circ}$ 130/2015. 
realizado em termos que aquela não se sinta coagida ${ }^{56}$; a proteção da vítima mediante o serviço de proteção por teleassistência ${ }^{57}$; a possibilidade das vítimas, que pretendam sair da sua habitação permanente para pôr termo à violência doméstica e não disponham de uma habitação alternativa, seja própria, seja do círculo de pessoas familiares ou amigos que a apoiam, contarem com a "rede nacional de apoio às vítimas de violência doméstica", composta por estruturas de atendimento, acolhimentos de emergência e "casas abrigo" 58 . Este apoio é totalmente gratuito e pode ser accionado, inclusive, por uma simples chamada telefónica, nomeadamente para o número 144, que corresponde à Linha Nacional de Emergência Social (LNES) 59 .

As estruturas de atendimento são compostas por "equipas técnicas que atendem, apoiam e encaminham as vítimas de violência doméstica" para os serviços ou autoridades que sejam adequados às necessidades da pessoa ofendida.

Os acolhimentos de emergência são habitações que alojam aquelas vítimas em situação de emergência, motivada esta sobretudo por ausência de uma habitação que garanta segurança à vítima e por receio desta de represálias do alegado agressor, por um período que pode estender-se até 15 dias ou, excecionalmente, até 30 dias.

As "casas abrigo" são residências que acolhem as vítimas de violência doméstica e respetivo agregado familiar que daquela dependam - sejam menores, sejam maiores com deficiência - até 6 meses ou, excecionalmente, até 1 ano. Este apoio visa garantir um acompanhamento que comece por assegurar estabilidade e segurança ao agregado e, seguidamente, permita aquela família edificar a sua autonomização em condições de segurança que afastem a reincidência da violência.

56 Artigo $20^{\circ}$, n. ${ }^{\circ} 3$, da Lei n. ${ }^{\circ} 112 / 2009$.

57 Artigo $20^{\circ}$, n. ${ }^{\circ}$ 4, da Lei n. $.^{\circ} 112 / 2009$. O serviço de teleassistência foi introduzido no nosso ordenamento jurídico pela Portaria n. ${ }^{\circ}$ 220-A/2010, de 16 de Abril, que já sofreu uma alteração imposta pela Portaria n. ${ }^{\circ} 63 / 2011$, de 3 de Fevereiro, e "assenta num sistema tecnológico constituído por um conjunto de equipamentos, aplicações informáticas e sistemas de comunicação e infra-estruturas técnicas que permitem apoiar as vítimas com necessidades especiais de protecção. Este sistema funciona com base na utilização de tecnologias de comunicação móvel e telelocalização, assegurando à vítima uma resposta rápida e eficaz perante situações de perigo/risco e apoio emocional permanente, vinte e quatro horas por dia e 365 dias por ano." Aquele serviço encontra-se sob a alçada da Comissão para a Cidadania e Igualdade de Género (CIG). Cf. https://www.cig.gov.pt/ teleassistencia-a-vitimas-de-violencia-domestica/.

580 diploma em vigor que regula aquelas estruturas de apoio às vítimas de violência doméstica é o Decreto Regulamentar n. ${ }^{\circ}$ 2/2018, publicado em Diário da República, 1.. ${ }^{\mathrm{a}}$ série - N. ${ }^{\circ} 17-24$ de Janeiro de 2018.

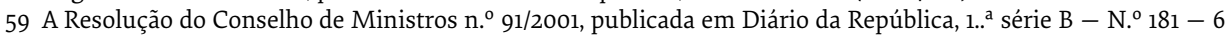
de Agosto de 2001, aprovou o "Plano Nacional de Acção para a Inclusão". Deste plano fez parte a criação do LNES e foi naquela data estabelecida a meta de criar "casas abrigo" para as vítimas de violência doméstica. No guia prático do Instituto da Segurança Social é definido que a LNES “é um serviço público, gratuito, de âmbito nacional, com funcionamento contínuo e ininterrupto ( $24 \mathrm{~h}$ por dia, todos os dias do ano), que tem como objetivo garantir resposta imediata a situações que necessitem de atuação emergente e urgente no âmbito da proteção social". Disponivel em: http://www.seg-social.pt/documents/10152/27217/N38_LNES/652c361e-4460-419f-97fd-3dde5ddab962. 
Quarto, o direito à restituição dos bens pertencentes à vítima, que se opera, por um lado, mediante a devolução célere dos objetos que lhe pertencem após a devida examinação no âmbito do processo penal ${ }^{60}$. E por outro, concretiza-se na possibilidade da vítima retirar da residência onde vivia com o alegado agressor os seus pertences pessoais e (quando possível) os bens móveis próprios, bem como os haveres dos menores ou maiores com deficiência que dependam da vítima. Para garantir a total segurança da vítima na recuperação dos referidos objetos, aquela pode-se fazer acompanhar das autoridades policiais ${ }^{61}$.

Quinto, o direito à antecipação da indemnização ${ }^{62}$, sem precludir o direito a ser ressarcida no âmbito do processo penal ${ }^{63}$. Embora a vítima de violência doméstica possa receber adiantadamente a indemnização concedida pelo Estado Português, mediante a prévia avaliação por parte da Comissão Nacional de Apoio às Vítimas de Crimes (CNAVC), pode ser compelida ao reembolso nas situações em que posteriormente venha a receber uma compensação económica para reparação, total ou parcial, dos danos sofridos ${ }^{64}$.

A referida antecipação da indemnização ocorre quando for perpetuado o crime de violência doméstica contra uma pessoa e esta em virtude desse crime fique sujeita a uma situação de grave carência económica. Esta compensação económica ${ }^{65}$ pode ascender até ao montante equivalente ao salário mínimo nacional e estender-se até 1 ano ${ }^{66}$.

Por fim, os direitos conferidos à vítima residente fora de Portugal passam, essencialmente, por medidas concretas que evitem que a distância geográfica se revele um entrave ao andamento normal do processo, ainda que a natureza seja urgente nos processos-crime de violência doméstica. Entre aquelas medidas evidenciam-se as declarações para memória futura logo após a participação e o recurso à videoconferência para as diligências judiciais ${ }^{67}$.

A vítima que reside noutro Estado da União Europeia pode, ainda, beneficiar de uma decisão de proteção europeia, que efetive as medidas de coação, injunções ou regras de conduta decretadas em sede de inquérito, ou, as penas principais ou acessórias proferidas na fase de julgamento ${ }^{68}$.

60 Artigo $21 .^{\circ}$, n. ${ }^{\circ}$ 3, Lei n. ${ }^{\circ} 112 / 2009$ e artigo $16 .^{\circ}$, n. ${ }^{\circ}$ 3, da Lei n. ${ }^{\circ} 130 / 2015$.

61 Artigo $21 .^{\circ}$, n. $^{\circ} 4$, Lei n. ${ }^{\circ} 112 / 2009$.

62 A Lei n. ${ }^{\circ}$ 104/2009, publicada em Diário da República, $1 . .^{a}$ série - N. ${ }^{\circ} 178$ - 14 de Setembro de 2009, aprovou "o regime de concessão de indemnização às vítimas de crimes violentos e de violência doméstica". Por sua vez, a Portaria n. ${ }^{\circ}$ 403/2012, publicada em Diário da República, 1. a $^{\text {serie }}$ - N. ${ }^{\circ} 237-7$ de Dezembro de 2012, aprovou "os modelos de requerimento para a concessão do adiantamento da indemnização por parte do Estado pelas vítimas de crimes violentos e de violência doméstica". De acordo com os referidos diplomas compete à CNAVC a análise e concessão das indemnizações. Cf. https://cpvc.mj.pt/.

63 Artigo $21 .^{\circ}$, n. ${ }^{\circ}$ 1, da Lei n. $.^{\circ} 112 / 2009$ e artigo $16 .^{\circ}$, n. ${ }^{\circ}$ 1, da Lei n. ${ }^{\circ}$ 130/2015.

64 Artigo $16 .^{\circ}$, n. ${ }^{\circ} 1$, da Lei n. ${ }^{\circ} 104 / 2009$

65 Artigo $5 \cdot^{\circ}$, n. ${ }^{\circ} 1$, da Lei n. ${ }^{\circ} 104 / 2009$.

66 Artigo $6 .^{\circ}$, n. ${ }^{\circ}$ 2, da Lei n. ${ }^{\circ}$ 104/2009.

67 Artigo $23 .{ }^{\circ}$, n. ${ }^{\circ}$ 2, da Lei n. ${ }^{\circ} 112 / 2009$, e artigo $19 .{ }^{\circ}$, n..$^{\circ}$ 3, da Lei n. ${ }^{\circ} 130 / 2015$.

68 Artigo $23 .^{\circ}$ n. $^{\circ} 1$ e n. ${ }^{\circ} 4$, da Lei n. $.^{\circ} 112 / 2009$. 


\section{Violência doméstica e estrangeiros em situação irregular em Portugal}

O crime de violência doméstica praticado em Portugal contra um estrangeiro é - na mesma medida em que fosse perpetuado contra um nacional, por força do princípio fundamental da equiparação ${ }^{69}$ - um atentado à sua dignidade humana, integridade física e moral, à liberdade e autodeterminação sexual, e até à proteção familiar, devendo, por isso, gozar dos mesmos direitos que um cidadão nacional.

A possibilidade de um estrangeiro se encontrar em situação irregular não deve(ria) diminuir a tutela da sua pessoa e família, motivo pelo qual deve(ria) ter ao seu dispor os direitos que assistem a outra vítima de violência doméstica, seja esta um cidadão nacional, cidadão europeu ou cidadão estrangeiro, que neste último caso se encontre ou resida em Portugal com habilitação documental legalmente válida.

Sucede que a denúncia do crime junto das autoridades judiciárias competentes efetuada por um cidadão estrangeiro, cuja entrada ou permanência em Portugal seja irregular, desencadeia a notificação do mesmo para comparecer no SEF ou pode mesmo provocar a sua detenção imediata pelas autoridades policiais. Por conseguinte e respetivamente, o cidadão estrangeiro será convidado a abandonar voluntariamente o país ${ }^{70}$ ou será expulso do território nacional ${ }^{71}$.

Deste modo, a vítima estrangeira que esteja em situação irregular em Portugal pode ser envolvida em dois processos, nomeadamente um processo-crime associado à violência doméstica e um processo administrativo com vista ao seu afastamento compulsório do país.

A correlação entre estes dois processos pode gerar uma situação atípica uma vez que o afastamento do território português pode-se efetivar em momento prévio à conclusão do processo-crime.

Ainda que o desenvolvimento processual deste último tenha um caráter urgente, pode não se revelar tão célere quanto o processo administrativo, dado que, por um lado, o SEF pode notificar o cidadão estrangeiro para abandonar voluntariamente o país no prazo de 10 a 20 dias $^{72}$, e, por outro, o SEF pode ter o dever de apresentar, no prazo de 48 horas, o cidadão ao tribunal competente para validar a decisão de afastamento coercivo ${ }^{73}$. Embora esta

69 Artigo $15 .^{\circ}, \mathrm{n} .{ }^{\circ} 1 \mathrm{da}$ CRP.

70 Artigo $138^{\circ}$, n. ${ }^{\circ}$, da Lei n. ${ }^{\circ}$ 23/2007. Conferir nota de rodapé n..$^{\circ} 33$.

71 Artigos $134 .^{\circ}, 140 .^{\circ}, 146 .^{\circ}$ e $181 .^{\circ}$ da Lei n. $.^{\circ} 23 / 2007$. Conferir nota de rodapé n. ${ }^{\circ} 33$.

72 Conferir nota de rodapé n..$^{\circ} 70$.

73 Artigo $146 .^{\circ}$ da Lei n. ${ }^{\circ} 23 / 2007$. 
última decisão seja suscetível de impugnação judicial, a lei apenas prevê que os efeitos da ação sejam meramente devolutivos ${ }^{74}$.

São diversas as vozes doutrinárias que apelam à igualdade plena (salvo, as restrições plasmadas no artigo $15^{\circ}$, n. $^{\circ} 2$ da CRP, que atentam, sobretudo, à soberania nacional estar reservada a cidadãos nacionais) entre os cidadãos portugueses e os cidadãos estrangeiros, o que a contrario sensu pode ser entendido como uma refutação contra a eventual expulsão dos cidadãos estrangeiros vítimas de violência doméstica, nos moldes (acima descritos) em que a lei portuguesa permite que seja efetuada, independentemente da regularidade, ou não, da situação de permanência ou residência no Estado Português.

JORGE MIRANDA, neste sentido, defende que "o princípio geral do Direito português na linha de uma bem ancorada e própria tradição - é de equiparação, de igualdade ou, talvez melhor, de extensão aos estrangeiros dos direitos conferidos aos portugueses. Mas a Constituição de 1976 vai mais longe, numa perspectiva universalista desconhecida das Constituições anteriores (...). Essa perspectiva universalista resulta da inserção dos direitos fundamentais no sentido decorrente da Declaração Universal dos Direitos do Homem (art. 16. ${ }^{\circ}$, n. 2)"75.

GOMES CANOTILHO pugna que "a equiparação dos cidadãos estrangeiros e dos apátridas aos cidadãos portugueses vale para todos os direitos, pelo que, além da tradicional paridade civil e dos clássicos direitos de liberdade, eles gozam também, em princípio, dos direitos de prestação, como, por exemplo, ao direito à saúde, ao ensino, à habitação, etc. (...) Os estrangeiros que não beneficiam de direitos sociais integrados nos sistemas sociais contributivos, beneficiam de prestações inerentes à garantia de um standard mínimo de existência, postulado pela dignidade da pessoa humana"76.

OLÍVIA GOMES entende que "submeter alguém a um processo de retirada compulsória de um país por sua situação irregular de permanência, após denúncia das agressões que sofreu, sem observância de seus direitos fundamentais, desrespeitando a sua dignidade e integridade, é colocar no mesmo patamar o fato de não ter os documentos necessários à permanência no país e o delito de violência doméstica"77.

74 Artigo $150 .^{\circ}$ da Lei n. ${ }^{\circ}$ 23/2007. A impugnação judicial deve ser concretizada mediante a ação administrativa para impugnação de atos administrativos, prevista no artigo $37 .^{\circ}, \mathrm{n} \cdot .^{\circ} 1$, alínea a) do CPTA. Sucede, porém, que a providência cautelar para a suspensão da eficácia de ato administrativo (prevista no artigo $112 .^{\circ}$, n. $^{\circ} 2$, alínea a) do CPTA) poderá salvaguardar melhor os interesses e direitos do cidadão estrangeiro dado a lei conferir caráter de urgência a este tipo de ação.

75 MIRANDA, Jorge; MEDEIROS, Rui - Constituição da República Portuguesa Anotada. Tomo I. Coimbra: Coimbra Editora, 2005, p. 132.

76 CANOTILHO, Gomes; MOREIRA, Vital - Constituição da República Portuguesa Anotada..., p. 357.

77 GOMES, Olívia Maria Cardoso - Violência Doméstica e Migrações - Estudo Comparado das Legislações Portuguesa, Brasileira e Espanhola sobre Violência Doméstica em Comunidades de Imigrantes. Curitiba: Editora Juruá, 2012, p. 103. 
A mesma autora defende que a irregularidade da situação de permanência ou residência em Portugal por parte de estrangeiros que sejam vítimas de violência doméstica pode ser colmatada com a hipótese de ser concedida uma autorização excecional de residência por razões humanitárias ${ }^{78}$. Ainda assim, eleva essa possibilidade sem grande entusiasmo dado que a referida autorização é atribuída pelo diretor nacional do SEF ou pelo membro do Governo responsável pela área da administração interna ${ }^{79}$, de um modo discricionário e sem qualquer obediência a critérios legais ou sequer ao Ministério Público.

A referida discricionariedade tem sido reflectida em diversos arestos, inclusive do Supremo Tribunal Administrativo, que tem pugnado pela atuação da Administração Pública na concessão, ou não, de autorização excepcional de residência ser «apenas sindicável nos seus aspectos vinculados, designadamente os relativos à competência, à forma, aos pressupostos de facto e à adequação ao fim prosseguido e, quanto aos "limites internos" do exercício desse poder, designadamente o respeito pelos princípios da igualdade, justiça e imparcialidade.» ${ }^{80}$

Isto quer dizer que a reação - mediante a ação de impugnação judicial - ao indeferimento da concessão da autorização de residência excepcional, por razões humanitárias ${ }^{81}$, a uma vítima de violência doméstica, terá que, no caso concreto, conter factos que concretizem ou corporizem bastante aquelas razões, dado que a jurisprudência tem defendido que somente erros grosseiros ou a aplicação manifestamente inadequada daquele critério podem possibilitar a inversão da decisão (administrativa) inicial de não concessão ${ }^{82}$.

Perante isto torna-se evidente que a vítima de violência doméstica numa situação irregular em Portugal possui mais um motivo para sentir-se inibida de denunciar o crime às autoridades, para além das razões típicas que influenciam uma vítima não pretender participar o crime. Estas, de um modo lato, estão associadas à relação de "poder-controlo" criada pelo alegado agressor sobre a vítima, que fazem esta ficar numa situação de dependência ou carência (afectiva, económica ou laboral, social, familiar, et caetera), que tornam sérias e elevadas as dificuldades para a vítima concretizar a rutura conjugal.

É habitual entre as referidas razões de dependência encontrar-se a presença de filhos em comum, que motivam (sendo que, em muitas ocasiões, apresenta-se mesmo como a

78 Ob. cit. nota de rodapé n. ${ }^{\circ} 77$, p. 102.

79 Artigo $123 .{ }^{\circ}$, n. ${ }^{\circ} 1$, da Lei n..$^{\circ}$ 23/2007. Conferir nota de rodapé n. ${ }^{\circ} 33$.

80 Conferir o Ac. do STA, proc. n..$^{\circ}$ 044852, de 07/02/2001 (consultado em 22/02/2019). Disponível em: http://www. dgsi.pt/.

81 Conferir o Ac. do STA, proc. n. ${ }^{\circ}$ 0272/02, de 31/10/2002 (consultado em 22/02/2019). Disponível em: http://www. dgsi.pt/.

82 Conferir nota de rodapé $n .^{\circ} 80$. 
principal causa) a vítima a permanecer na relação com o alegado agressor ambicionando, ainda, uma família unida.

Ainda que esta intenção de permanência não configure a situação ideal para a vítima uma vez que mantém-se sujeita ao perigo de incorrer em mais danos, cuja tendência neste contexto pauta-se pela gravidade das condutas serem crescentes, pretende-se, agora, refletir em que medida a "fragilidade" da vítima estrangeira em situação irregular em Portugal -, caracterizada pelo seu afastamento do território poder verificar-se em momento prévio à apreciação judicial do crime de violência doméstica, - pode ser equilibrada pela sua intenção de permanecer junto da família.

Por outras palavras e de modo interrogativo: a protecção da vida familiar dos estrangeiros em situação irregular pode configurar um limite efectivo ao princípio da soberania territorial?

A protecção da vida familiar é uma incumbência do Estado e da sociedade ${ }^{83}$, tendo em consideração que a família é apreciada como um elemento fundamental da sociedade ${ }^{84}$.

GOMES CANOTILHO e VITAL MOREIRA ensinam que a família é uma "instituição jurídica necessária" porque trata-se de um "fenómeno da vida, e não, uma criação jurídica." ${ }^{85}$ Mais defendem que "o direito à convivência" é a expressão mais frequente e preponderante da unidade familiar que carece da referida protecção, razão pela qual deverão haver normas que garantam a reunião ou impeçam a separação dos membros da família. ${ }^{86}$

A referida reunião ou não separação familiar deve ser garantida pelo Estado Português quer aos cidadãos nacionais, quer aos cidadãos estrangeiros, sendo que a estes últimos é garantido, ainda, por força dos ditames jurídicos decorrentes de tratados ou convenções internacionais e dos princípios constitucionais, o direito ao reagrupamento familiar. ${ }^{87}$ Nesta esteira, a nossa Lei Fundamental prescreve o princípio do não afastamento dos filhos dos pais, desde que estes assumam os seus deveres para com os menores ${ }^{88}$.

Acontece que os pais que não zelem pelo cumprimento daqueles deveres poderão ser afastados mediante, sempre, uma decisão judicial, evidenciando a soberania e autonomia do Estado em impor regras que poderão impedir a protecção da unidade familiar. Assim como e em prol do supremo interesse da criança, o Estado poderá através de uma decisão

83 Por força do artigo $18 .^{\circ}, \mathrm{n} .^{\circ}$ 3, da CRP, as entidades privadas devem respeitar os "preceitos constitucionais respeitantes aos direitos, liberdades e garantias".

84 Artigo $67 .^{\circ}$ da CRP.

85 Ob. cit. nota de rodapé n. ${ }^{\circ} 31$, página 856.

86 Ob. cit. nota de rodapé n. ${ }^{\circ} 31$, páginas 857 e 858 .

87 PINTO, Ana Luísa; CANOTILHO, Mariana - O Tratamento dos Estrangeiros e das Minorias na Jurisprudência Constitucional Portuguesa. In Estudos em Homenagem ao Conselheiro José Manuel Cardoso da Costa. Vol. II. Coimbra: Coimbra Editora, 2005, p. 231.

88 Artigo $36 .^{\circ}$, n. ${ }^{\circ}$ 6. da CRP. 
judicial, mais do que limitar os convívios dos menores com os progenitores, inibir o exercício das responsabilidades parentais ${ }^{89}$.

Contanto que o estrangeiro esteja regular em Portugal, o facto de ser pai ou mãe não garante o direito absoluto de permanecer no nosso território e evitar o afastamento decorrente da decisão administrativa ou judicial. Tanto assim é que a lei prevê como limite à expulsão a situação dos estrangeiros que "tenham filhos menores, nacionais de Estado terceiro, residentes em território português, relativamente aos quais assumam efetivamente responsabilidades parentais e a quem assegurem o sustento e a educação" ${ }^{\circ}$. A contrario sensu, depreende-se que aqueles progenitores que não cumpram os seus deveres parentais não gozarão do direito de permanência no Estado Português.

No entanto, o estrangeiro não pode gozar do referido limite legal à expulsão quando se encontre irregular em Portugal. Ainda que o afastamento de um estrangeiro irregular em Portugal o impeça de conviver com as crianças de quem seja progenitor e, de um modo lato, do exercício das responsabilidades parentais, aquela decisão administrativa não tem por objectivo impedir a união familiar, mas tão-somente aplicar uma consequência pela violação das normas que regulam a entrada e permanência no território. Em termos práticos, esta posição pode ser mais um argumento dissuasor para o estrangeiro vítima de violência doméstica optar pelo silêncio e garantir o contato com os filhos ou filhas, ao invés de participar o crime às autoridades e deixar de viver no que a doutrina define de terrorismo íntimo ${ }^{91}$.

Posto isto, conclui-se que sobrepõe-se o princípio da soberania territorial ao princípio da protecção da vida familiar dos estrangeiros que estejam em situação irregular e, com isso, eleva-se a desprotecção do estrangeiro vítima de violência doméstica, que vê a sua dignidade humana ser esmagada pela ilegalidade documental, sem pesar que esta última pode até ser provocada no âmbito da relação de "poder-controlo" que subjuga a pessoa ofendida ao agente do crime.

Em Portugal, a protecção dos direitos fundamentais a estrangeiros que se encontrem documentalmente ilegais não pode resumir-se à participação do crime às autoridades e à (mera) expectativa que o processo-crime vai percorrer as fases processuais ordinárias sem garantia efectiva que o agente de crime seja, ou não, acusado, pronunciado ou condenado, enfraquecendo-se a tutela jurisdicional efectiva, que "para defesa dos direitos, liberdades e

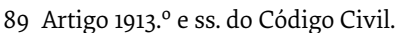

90 Artigo $135 .^{\circ}$, n. ${ }^{\circ}$, alínea c), da Lei n. ${ }^{\circ} 23 / 2007$.

91 JOHNSON, Michael - Violence and Abuse in Personal Relationships: Conflict, Terror, and Resistance in Intimate Partnerships. New York: Cambridge University Press, 2006, pp. 557-576. 
garantias pessoais, (...) assegura aos cidadãos procedimentos judiciais caracterizados pela celeridade e prioridade".

Qualquer tentativa no sentido de suportar que o decurso do processo-crime não é inviabilizado pela irregularidade documental da vítima estrangeira - porque, por exemplo, pode a vítima prestar declarações para memória futura ${ }^{92}$, que servirá de prova em audiência de julgamento, ou podem ser aplicadas medidas de coacção ao arguido que decretem a proibição de contactos - fica aquém quando a vítima vê restringidos os seus direitos fundamentais que, nestas circunstâncias, são concretizados em diversos apoios, tais como: habitacional (inclusive, "casas abrigo"93), económico (por exemplo, o rendimento social de inserção), profissional (por exemplo, prioridade em obter trabalho ou formação profissional), educacional (por exemplo, não ter acesso a formas de aprendizagem da língua portuguesa).

Urge, assim, uma alteração à nossa Lei que regula a "Entrada, Permanência, Saída e Afastamento de Estrangeiro do Território Nacional" com vista a contemplar com efetividade a proteção dos estrangeiros que sejam vítimas de violência doméstica.

Para o efeito, o legislador nacional pode até seguir o exemplo do seu congénere espanhol, que impôs em 2009 pela "Ley Orgánica 2/2009", de 11 de Dezembro, uma alteração à "Ley Orgánica 4/2000", de 11 de Janeiro, sobre os direitos e liberdades dos estrangeiros em Espanha, prevendo no seu artigo $31 .^{\circ}$, n. ${ }^{\circ} 3$, a concessão de uma autorização de residência temporária, por razões humanitárias, que possibilitem a colaboração com a justiça, o que seguramente assegura à vítima de violência doméstica a participação no processo-crime até à decisão final ${ }^{94}$.

\section{Considerações finais}

Em plena era de globalização, a livre circulação de pessoas colide com as normas impostas por Portugal, demais Estados-membros da União Europeia e até pela própria União, que limitam o acesso ou repelem os estrangeiros daqueles territórios ${ }^{95}$.

92 Conferir nota de rodapé n. ${ }^{\circ} 67$.

93 Artigo $40^{\circ}, n .^{\circ}$ 3, do Decreto Regulamentar n. ${ }^{\circ}$ 2/2018 estatui que: "o alojamento compreende, ainda, a prestação de serviços básicos, nomeadamente alimentação, higiene, proteção e segurança."

94 A referida lei foi publicada no Boletín Oficial del Estado, n. ${ }^{\circ}$ 299, em 12/12/2009, pág. 104986 a 105031 (consultado em 07/05/2019). Disponível em: https:/www.boe.es/boe/dias/2009/12/12/pdfs/BOE-A-2009-19949.pdf

$\mathrm{O}$ artigo $31 .^{\circ}$, sob a epígrafe "Situación de residencia temporal", estatui no seu n. ${ }^{\circ} 3$ o seguinte:

La Administración podrá conceder una autorización de residencia temporal por situación de arraigo, así como por razones humanitarias, de colaboración con la Justicia u otras circunstancias excepcionales que se determinen reglamentariamente. En estos supuestos no será exigible el visado.

95 SOUSA, Constança Urbano de - Cidadania da Europeia à venda?. Observare - Universidade Autónoma de Lisboa, 2016. [Consultado em 07 de Maio de 2019]. Disponível em: http://janusonline.pt/images/anuario2015/1.6_ ConstancaSousa_cidadaniaUE.pdf. 
A partir deste pressuposto legal questiona-se na presente reflexão em que medida a proteção da vida familiar dos estrangeiros, que se vejam envolvidos numa situação de violência doméstica e estejam em situação irregular, pode ser um limite efetivo ao princípio da soberania territorial em matéria de direito dos estrangeiros?

É uma questão preocupante nos tempos atuais dado que a violência doméstica é um flagelo social que não tem fronteiras e pode atingir qualquer pessoa, independentemente da sua origem, cultura, língua, instrução, capacidade económica, profissão, religião, idade, orientação sexual, saúde, et caetera.

A inquietação eleva-se quando os dados apontam, por um lado, que em 2013 cerca de 35 por cento das mulheres no mundo tinham sido ofendidas física ou sexualmente pela pessoa com quem mantinham, ou não, um relacionamento habitual ${ }^{96}$.

Por outro lado, os índices de femicídio verificados em Portugal mais elevados situaram-se em 2014, no qual se registaram a consumação de 43 homicídios contra mulheres ${ }^{97}$. Além de que, desde o ano 2004 até 2018, a taxa de femicídio situa-se numa impressionante média de 35 a 36 vítimas por ano.

E por fim, a violência doméstica em Portugal tem sido mais disseminada por e entre cidadãos portugueses do que estrangeiros. No entanto, estes últimos - e, em particular, as vítimas, que são o enfoque desta análise - podem estar sujeitos ao afastamento do território nacional caso estejam numa situação irregular, o que pode condicionar o desenvolvimento ou conclusão do processo-crime.

Para se apreender melhor as considerações deste estudo, importa ter presente a noção legal de violência doméstica e a caraterização da sua dinâmica.

Assim, convoca-se o conceito previsto na Convenção de Istambul, que no artigo $3^{\circ}$, alínea b), estatui que: «"violência doméstica" designa todos os actos de violência física, sexual, psicológica ou económica que ocorrem no seio da família ou do lar ou entre os actuais ou ex-cônjuges ou parceiros, quer o infractor partilhe ou tenha partilhado, ou não, o mesmo domicílio que a vítima"».

Por sua vez, recorremos ao modelo de "Duluth"98 para dar conta que estamos perante uma situação de violência doméstica quando a relação entre duas pessoas é pautada pela tentativa e consumação de uma ter o "poder-controlo" sobre a outra. E este "poder-controlo" é concretizado, de modo cíclico e repetido, mediante as seguintes fases: primeiro a fase da "lua-de-mel" ou da sedução; segundo, a fase da agressão ou da violência; terceira, a fase do arrependimento ou do perdão.

96 Conferir nota de rodapé $n .^{\circ} 2$.

97 Conferir nota de rodapé n. ${ }^{\circ} 4$.

98 Conferir nota de rodapé n. ${ }^{\circ} 20$. 
Em Portugal, verificando-se a existência daquele "poder-controlo" de um modo abusivo, pode-se preencher o crime de violência doméstica, punido e previsto no artigo $152 . .^{\circ}$ do Código Penal ${ }^{99}$, quer a vítima se trate de um cidadão nacional, quer estrangeiro.

Perante aquele crime, a vítima beneficia de um conjunto de direitos e garantias fundamentais, que, reitera-se, são idênticos para os cidadãos portugueses e estrangeiros, por força do princípio da equiparação previsto no artigo $15 .^{\circ}$ da CRP.

Entre os referidos direitos destacam-se pela relevância para este estudo os seguintes: o direito de apresentar queixa, sendo certo que, para o efeito, a vítima estrangeira pode em Portugal contar com o auxílio de entidades que apoiam vítimas de violência doméstica ou apoiam imigrantes ${ }^{100}$; o direito à informação, que no caso de a vítima ser estrangeira se pode resumir a que aquela possa compreender como se processa o processo-crime e possa ser compreendida ${ }^{101}$; o acesso ao direito, que se concretiza na vítima poder usufruir de uma consulta jurídica, para ser devidamente aconselhada ou orientada, e poder fazer-se acompanhar de advogado perante qualquer autoridade; o direito à proteção para garantir à vítima medidas adequadas que visem afastar situações de revitimação, de represálias ou de forte perturbação da sua privacidade ${ }^{102}$; o direito à restituição dos bens pertencentes à vítima e familiares, que estejam na sua dependência ${ }^{103}$; o direito à antecipação da indemnização, sem precludir o direito da vítima ser ressarcida pecuniariamente no âmbito do processo penal ${ }^{104}$; o direito da vítima prestar declarações para memória futura, logo após a participação, e o direito a recorrer à videoconferência para as diligências judiciais, de modo a evitar que a distância geográfica se revele um entrave ao andamento normal do processo-crime ${ }^{105}$.

A eventualidade da vítima estrangeira encontrar-se em situação irregular não deve(ria) diminuir a tutela da sua pessoa e família, nem deve(ria) restringir os direitos que assistem a uma vítima de violência doméstica.

Acontece que a denúncia do crime junto das autoridades judiciárias competentes efetuada por um cidadão estrangeiro em situação irregular, desencadeia a notificação do mesmo para comparecer no SEF ou pode mesmo provocar a sua detenção imediata pelas autoridades policiais, o que por conseguinte pode, respetivamente, provocar que o mesmo seja convidado a abandonar voluntariamente o país ou seja expulso do território nacional ${ }^{106}$.

99 Conferir nota de rodapé n. ${ }^{\circ} 14$.

100 Conferir notas de rodapé n. ${ }^{\circ} 39$ a 45 .

101 Conferir nota de rodapé n. ${ }^{\circ} 51$.

102 Conferir nota de rodapé n. ${ }^{\circ} 54$.

103 Conferir nota de rodapé n. ${ }^{\circ} 60$.

104 Conferir notas de rodapé n. ${ }^{\circ} 62$ e 63 .

105 Conferir nota de rodapé n. ${ }^{\circ} 67$.

106 Conferir notas de rodapé n. ${ }^{\circ} 70$ e 71 . 
Perante isto, a vítima estrangeira que esteja em situação irregular em Portugal pode ser envolvida em dois processos, um processo-crime associado à violência doméstica e outro processo administrativo com vista ao seu afastamento compulsório do país. E a relação entre aqueles processos pode gerar uma situação atípica uma vez que o afastamento do território português pode-se efetivar em momento prévio à conclusão do processo-crime.

"Submeter alguém a um processo de retirada compulsória de um país por sua situação irregular de permanência, após denúncia das agressões que sofreu, sem observância de seus direitos fundamentais, desrespeitando a sua dignidade e integridade, é" no entendimento de OLÍVIA GOMES "colocar no mesmo patamar o fato de não ter os documentos necessários à permanência no país e o delito de violência doméstica”107.

Em face desta apreciação torna-se evidente que a vítima de violência doméstica, numa situação irregular em Portugal, possui mais um motivo para sentir-se inibida de denunciar o crime às autoridades, até porque havendo filhos em comum com o alegado agressor, a vítima pode sentir- se forçada a permanecer na relação ambicionando, ainda, uma família unida.

Ainda que aquela intenção da vítima não denunciar o crime e permanecer junto do alegado agressor para não ser afastada dos filhos em comum não configure a situação ideal, dado que mantém-se sujeita ao perigo de incorrer em mais danos, questiona-se em que medida a "fragilidade" da vítima estrangeira em situação irregular em Portugal -, caracterizada pelo seu afastamento do território poder verificar-se em momento prévio à apreciação judicial do crime de violência doméstica, - pode ser equilibrada pela sua intenção de permanecer junto da família sem estar a ser vitimizada.

A não separação familiar deve ser garantida pelo Estado Português quer aos cidadãos nacionais, quer aos cidadãos estrangeiros, sendo que a estes últimos é garantido, ainda, por força dos ditames jurídicos decorrentes de tratados ou convenções internacionais e dos princípios constitucionais, o direito ao reagrupamento familiar ${ }^{108}$.

No entanto, o simples facto de um estrangeiro - que esteja regular em Portugal - ser pai ou mãe não lhe dá garantia absoluta de permanecer no nosso território e evitar o afastamento decorrente da decisão administrativa ou judicial. Tanto assim é que a lei prevê como limite à expulsão a situação dos estrangeiros que "tenham filhos menores, nacionais de Estado terceiro, residentes em território português, relativamente aos quais assumam efetivamente responsabilidades parentais e a quem assegurem o sustento e a educação"109.

107 Conferir notas de rodapé $n .^{\circ} 77$.

108 Conferir notas de rodapé $n .{ }^{\circ} 87$.

109 Conferir nota de rodapé n. ${ }^{\circ} 90$. 
Porém, o estrangeiro não pode gozar do referido limite legal à expulsão quando se encontre irregular em Portugal. Ainda que o seu afastamento possa ser um impedimento ao convívio com as crianças de quem seja progenitor, aquela decisão administrativa não tem por objectivo impedir a união familiar, mas tão-somente aplicar uma consequência pela violação das normas que regulam a entrada e permanência no território.

Deste modo, conclui-se que o princípio da soberania territorial sobrepõe-se ao princípio da protecção da vida familiar dos estrangeiros que estejam em situação irregular e, por conseguinte, potencia-se a desprotecção do estrangeiro vítima de violência doméstica, que vê a sua dignidade humana ser esmagada pela ilegalidade documental, sem ter em conta que esta última pode até ser provocada no âmbito da relação de "poder-controlo" que vincula a pessoa ofendida ao agente do crime.

Torna-se, assim, necessário e urgente a alteração à lei portuguesa que regula a "Entrada, Permanência, Saída e Afastamento de Estrangeiro do Território Nacional", e, para o efeito, o legislador nacional até pode seguir o exemplo do seu congénere espanhol ${ }^{110}$, com vista a contemplar efetivamente a proteção dos estrangeiros que sejam vítimas de violência doméstica, afastando-se assim a redução dos seus direitos à participação do crime às autoridades e à (mera) expectativa que o processo-crime vai ser finalizado antes de ser concretizado o seu afastamento do território nacional por estarem em situação irregular.

\section{REFERÊNCIAS BIBLIOGRÁFICAS}

ALBUQUERQUE, Paulo Pinto de - Comentário do Código Penal à luz da Constituição da República e da Convenção Europeia dos Direitos do Homem. 3. ${ }^{\text {a }}$ ed. Porto: Universidade Católica Portuguesa, 2015.

BRANDÃO, Nuno - Bem Jurídico e Direitos Fundamentais entre a Obrigação Estadual de Protecção e a Proibição do Excesso. In Estudos em Homenagem ao Prof. Doutor Manuel da Costa Andrade. Coimbra: Instituto Jurídico, 2017.

CANOTILHO, Gomes; MOREIRA, Vital - Constituição da República Portuguesa Anotada. Vol. I. 4.. ${ }^{\text {a }}$ ed. rev. Coimbra: Coimbra Editora, 2007.

CARVALHO, Taipa de - Comentário Conimbricense do Código Penal, Tomo I, Coimbra, Coimbra Editora, 1999.

FERNANDES, Plácido Conde - Violência doméstica: novo quadro penal e processual penal. In Revista do CEJ. Lisboa. ISSN 1645-829X. N. ${ }^{\circ} 8,2004$, p. 239-340.

GARCIA, M. Miguez; RIO, J. M. Castela - Código Penal Anotado. Lisboa: Almedina, 2015.

GOMES, Olívia Maria Cardoso - Violência Doméstica e Migrações - Estudo Comparado das Legislações Portuguesa, Brasileira e Espanhola sobre Violência Doméstica em Comunidades de Imigrantes. Curitiba: Editora Juruá, 2012.

JOHNSON, Michael - Violence and Abuse in Personal Relationships: Conflict, Terror, and Resistance in Intimate Partnerships. New York: Cambridge University Press, 2006.

110 Conferir nota de rodapé n. ${ }^{\circ} 94$. 
MIRANDA, Jorge; MEDEIROS, Rui - Constituição da República Portuguesa Anotada. Tomo I. Coimbra: Coimbra Editora, 2005.

NAÇÕES UNIDAS - World Population Prospects: The 2012 Revision, Volume II, Demographic Profiles. [Consultado em 07 de Maio de 2019]. Disponível em: https://population.un.org/wpp/Publications/Files/ WPP2012_Volume-II-Demographic-Profiles.pdf

OLIVEIRA REIS, Catarina (Coord.); GOMES, Natália - Indicadores de Integração de Imigrantes: Relatório Estatístico Anual de 2016. Lisboa: Alto Comissariado para as Migrações, 2016.

ORGANIZAÇÃO MUNDIAL DA SAÚDE - Estimativas globais e regionais da violência contra as mulheres: prevalência e efeitos da violência conjugal e da violência sexual não conjugal na saúde. [Consultado em 07 de Maio de 2019]. Disponível em: http://apps.who.int/iris/bitstream/handle/10665/85239/9789241564625 _eng.pdf?sequence $=1$

PINTO, Ana Luísa; CANOTILHO, Mariana - O Tratamento dos Estrangeiros e das Minorias na Jurisprudência Constitucional Portuguesa. In Estudos em Homenagem ao Conselheiro José Manuel Cardoso da Costa. Vol. II. Coimbra: Coimbra Editora, 2005.

PORTUGAL - Sistema de Segurança Interna - Relatório Anual de Segurança Interna de 2013. [Consultado em 07 de Maio de 2019]. Disponível em: https://www.portugal .gov.pt/media/1391220/RASI\%202013.pdf

PORTUGAL - Sistema de Segurança Interna - Relatório Anual de Segurança Interna de 2017. [Consultado em 07 de Maio de 2019]. Disponível em: https://www.portugal.gov.pt /download-ficheiros/ficheiro.aspx? $\mathrm{v}=9$ fod $7743-7 \mathrm{~d} 45-40 \mathrm{f} 3-8 \mathrm{cf} 2-\mathrm{e} 448600 \mathrm{f} 3 \mathrm{af} 6$

ROCHA-TRINDADE, Maria Beatriz - Sociologia das Migrações. Lisboa: Universidade Aberta de Lisboa, 1995.

SÁ GOMES, Catarina - O Crime de Maus Tratos Físicos e Psíquicos Infligidos ao Cônjuge ou ao Convivente em Condições Análogas às dos Cônjuges. Lisboa: AAFDL, 2004.

SOUSA, Constança Urbano de - Cidadania da Europeia à venda?. Observare - Universidade Autónoma de Lisboa, 2016. [Consultado em 07 de Maio de 2019]. Disponível em: http://janusonline.pt/images/ anuario2015/1.6_ConstancaSousa_cidadaniaUE.pdf.

TOGNI, Paula (coord.); RAPOSO, Paulo - Fluxos Matrimonais Transnacionais entre Brasileiras e Portugueses: Género e Imigração. Estudos do Observatório da Migração do Alto Comissariado para as Migrações, n. ${ }^{\circ} 38$, Lisboa, 2009.

UMAR - Relatório do Observatório de Mulheres Assassinadas. [Consultado em 07 de Maio de 2019]. Disponivel em: http://www.umarfeminismos.org/images/stories/noticias /OMA_FEMIC\%C3\%8DDIO_ Relat\%C3\%B3rio_2018_em_18_02_2019.pdf 